\title{
A casa que habito a casa que habita em mim
}

\section{The house that $i$ live in the house that lives in me}

\begin{abstract}
Lígia Mara Santos
Professora/Artisteira. Propositora de invencionices brincantes com crianças pequenas. Habitante de muitas casas: Casa/Chão; Casa/Vento; Casa/Infância; Casa/Porão; Casa/Invenção; Casa/Escola; Casa/Voo; Casa/Ficção; Casa/Sonho; Casa/Pesquisa; Casa/Devaneio; Casa/Teatro; Casa/Escritura. Professora do Núcleo de Desenvolvimento Infantil (NDI) do Centro de Ciências da Educação (CED) da Universidade Federal de Santa Catarina (UFSC). Doutoranda em Teatro pela Universidade do Estado de Santa Catarina (UDESC).

ligiasantos234@gmail.com - https://orcid.org/0000-0001-5294-2145
\end{abstract}

\section{Resumo}

Este texto refere-se ao trabalho desenvolvido com crianças pequenas numa instituição de Educação Infantil. O trabalho cotidiano com as crianças se inspira em movimentos que compõem Invenções Brincantes/Artísticas. Na combinação de elementos advindos da psicomotricidade, principalmente na perspectiva dos autores franceses Bernard Aucouturier e Andre Lapierre; e outros da arte, tendo por referência artistas como Lygia Clark, Elisa Bracher, Hélio Oiticica, Amélia Toledo, Deborah Colker, Leandro Selister, brotam as Invenções Brincantes/Artísticas. O trabalho é pensado e tramado oportunizando que as crianças brinquem com a arte, com os artistas, com as obras, com as proposições, com os materiais e com as técnicas. Espaços e tempos de brincadeira nos quais as crianças criam. Um dos intuitos das Invenções Brincantes/Artísticas é o de permitir que o corpo infantil sobrevenha, priorizando um espaço-tempo nas rotinas escolares para um trabalho de cunho corporalartístico. O corpo-arte instigando o desejo infantil de experimentar e de conhecer, um espaçotempo para manifestação do que pode um corpo infantil. No início do ano de 2017, uma dupla de professoras define $A C A S A$ como alusão para o trabalho com as crianças no decorrer daquele ano. A CASA foi, portanto, o elemento que nutriu a poesia e o pensamento sobre as coisas do mundo. A arte contemporânea em diálogo com a linguagem performática, o teatro, o cinema, a dança e a literatura deram subsídios para a reflexão sobre corpo e infância no espaço escolar.

Palavras-chave: Artes cênicas e crianças. Linguagem corporal na arte. Brincadeiras na arte. Performance (Arte)

\section{Abstract}

This text refers to the work developed with young children in an early preschool education institution. The daily work with children is inspired by movements that make up Playful/Artistic Inventions. In the combination of elements arising from relational psychomotricity, mainly from the perspective of French authors, Bernard Aucouturier and Andre Lapierre, and others from art, such as artists such as Lygia Clark, Elisa Bracher, Hélio Oiticica, Amélia Toledo, Deborah Colker, Leandro Selister, the Playful/Artistic Inventions sprout. The work is thought and planned, allowing children the opportunity to play with art, with artists, with works, propositions, materials and techniques. Spaces and times for playing are those in which children create.One of the aims of Playful/Artistic Inventions is to allow the child's body to arise, prioritizing a spacetime in school routines for body-artistic work. The body-art instigating the child's desire to try out and to know, a space-time for the manifestation of what a child's body can. At the beginning of 2017, a pair of teachers defined $A C A S A$ as an allusion to work with children during that year. $A C A S A$ was, therefore, the element that nourished poetry and thought about the things of the world. Contemporary art in dialogue with performatic language, theater, cinema, dance and literature provided support for reflection on body and childhood in the school space.

Keywords: Performing arts and children. Body language in art. Play in art. Performance art. 


\section{A CASA QUE HABITO}

\section{A CASA QUE HABITA EM MIM}

Este texto refere-se ao trabalho arquitetado com crianças pequenas numa escola de Educação Infantil ${ }^{1}$. Nessa instituição foi desenvolvida a experiência de dois trabalhos sobre casa: A Casa é Sua e Em casa. O presente texto esboça os primeiros movimentos com a escrita, ainda em processo, sobre a proposição A Casa é Sua. Os trabalhos sobre casa compõem o que provisoriamente tenho denominado Invenções Brincantes/Artísticas.

As Invenções Brincantes/Artísticas são pensadas e tramadas no sentido de oportunizar às crianças a brincadeira com a arte, com os artistas, com as obras, com as proposições, com os materiais e com as técnicas. São espaços e tempos de brincar nos quais as crianças criam.

Um dos intuitos das Invenções Brincantes/Artísticas é o de permitir que o corpo infantil sobrevenha, priorizando um espaço-tempo nas rotinas escolares para um trabalho de cunho corporal-artístico. O corpo-arte instigando o desejo infantil de experimentar e de conhecer, um espaço-tempo para manifestação do que pode um corpo infantil.

Diferentes artistas e suas obras foram referência para o trabalho com as crianças e deram subsídio para pensar nossas casas/invenções. Entre os artistas destacam-se os trabalhos de Lygia Clark, Hélio Oiticica, Deborah Colker, Charlie Chaplin, Hundertwasser, Antoni Gaudí, Amélia Toledo, Ernesto Neto, Leda Catunda, Patrick Dougherty, Vinicius de Moraes e Arnaldo Antunes.

Na proposição A Casa é Sua, Gaston Bachelard com sua "poética do espaço" nos inspirou a pensar a casa em seus mais variados sentidos. Passamos pelos segredos mais obscuros do porão até o acolhimento dos ninhos, dos cantos e dos redondos.

O texto se faz por fragmentos, poesias e imagens, que tramados compõem um pensamento sobre infância. Ficções sobre uma infância/casa.

\footnotetext{
1 Núcleo de Desenvolvimento Infantil (NDI), vinculado ao Centro de Ciências da Educação (CED) da Universidade Federal de Santa Catarina (UFSC).
} 
Não somente nossas lembranças como também nossos esquecimentos estão alojados. Nosso inconsciente está alojado. Nossa alma é uma morada. E, lembrando-nos das casas, dos aposentos, aprendemos a morar em nós mesmos. Já podemos ver que as imagens da casa caminham nos dois sentidos: estão em nós tanto quanto estamos nelas. (BACHELARD, 1989, p.20, grifo nosso)

Há muito e muito tempo,

Uma casa mora em mim.

Foi chegando de maneira imperceptível, e

Alojando-se para ficar...

\section{CASATEXTOCASATEXTOCASATEXTOCASA}

[...] minha casa é o mar aberto

[...] minha casa é minha coleção de cacos

[...] minha casa é minha língua estrangeira (MARQUES, 2017, p.43)
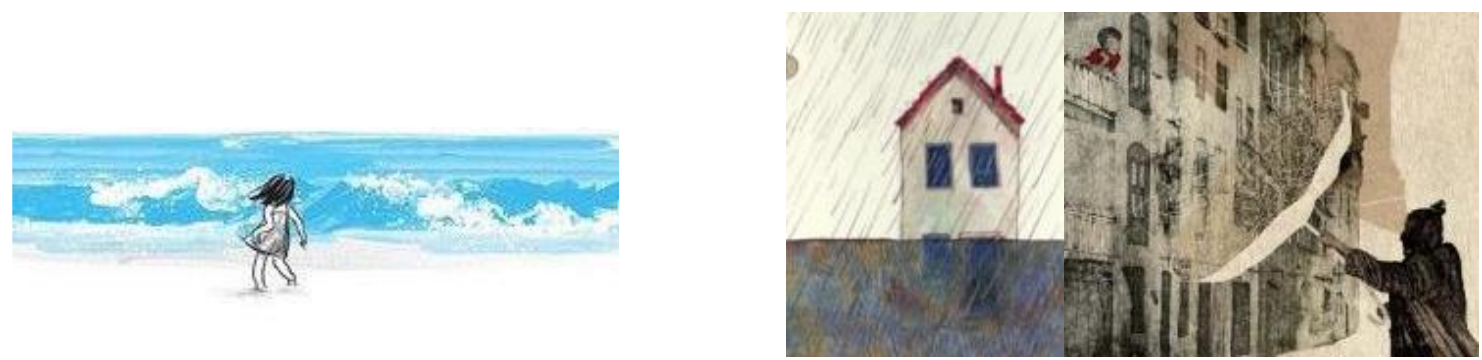

FIG. 1: Casas. Ilustração de livros infantis. Suzy Lee, Odilon Moraes, Kaatje Vermeire.

Fonte: https://www.soumae.org/livro-infantil-la-e-aqui-fala-sobre-separacao-dos-pais/

http://festivaldulivre.com/edition2012/selection/ - Acesso em 20/02/2020. 


\section{A Casa é Sua...}

No início de 2017, numa escola de educação infantil, uma dupla de professoras ${ }^{2}$ define a casa como alusão para o trabalho com as crianças ${ }^{3}$ no decorrer daquele ano.

- Psiu, psiu!

- Ei! O que vamos partilhar agora com você é uma história que aprendemos a observar atentamente no transcorrer de um tempo...

- Nem tudo será contado com todos os detalhes, esta é uma história que necessita de muita fantasia, para entender também o que não será dito. Uma história construída a partir das pequenas coisas cotidianas que vibram e convocam nosso olhar e nossa escuta.

\section{- Por favor, entre! $\boldsymbol{A}$ Casa é Sua...}

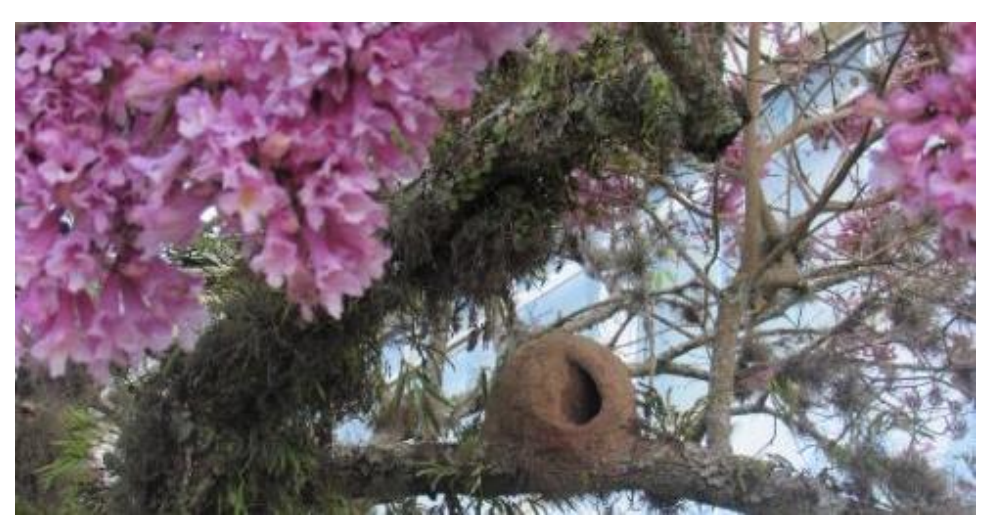

FIG. 2: Casa de joão-de-barro. Fotografia.

Fonte: Arquivo pessoal da autora. Data: 2017.

O percurso inicia com Casas de Pássaros...

Imagens, poesias e histórias passam a habitar nossos lugares!

\footnotetext{
2 Josiana Piccolli e Lígia Mara Santos.

${ }^{3}$ As crianças que participaram do Projeto A Casa é Sua tinham idade compreendida entre três e cinco anos.
} 


\section{SOBRE VOOS}

As histórias que inauguraram nossos encontros naquele ano foram compostas por textopoemas de Lalau e desenho-pinturas de Laurabeatriz 4 . Os pássaros contam o que veem quando voam sobre diferentes regiões do Brasil, aves brasileiras fabulam sobre suas paisagens.

Embalados por voos, poemas e paisagens, construímos uma atmosfera em nossa varanda:

Imagens de pássaros,

Ninhos dependurados,

Pássaros por todos os cantos; no alto, no chão, voando!!!

Poemas,

Poemas que moram em ninhos,

Ninhos que abrigam nossa imaginação!!!
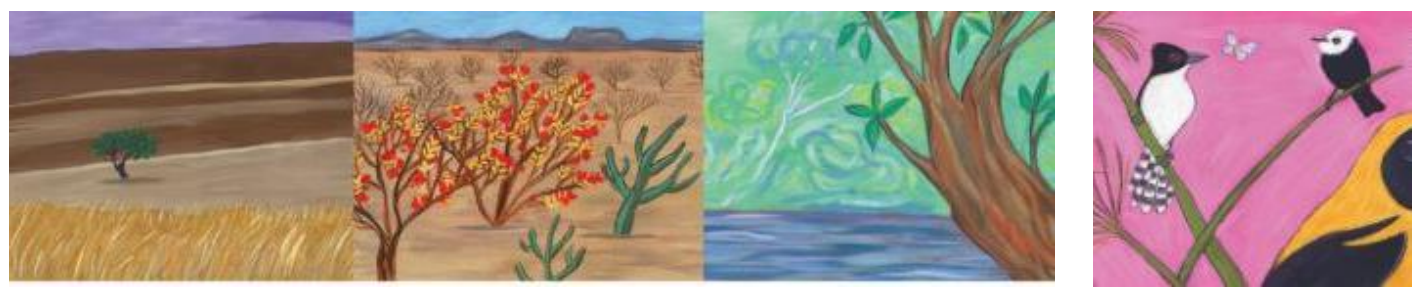

FIG. 3: Passarinhos do Brasil: poemas que voam. Ilustrações de Laurabeatriz.

Fonte:https://www.editorapeiropolis.com.br/produto/passarinhos-do-brasil/ - Acesso em: 19/02/2020

${ }^{4}$ Passarinhos do Brasil: Poemas que voam e Sobre Voos. 
A Casa é Sua! Uma contextura sobre casas vai surgindo e misturando-se com as histórias e voos dos pássaros.

Pensamentos sobre casas foram pairando e inspirando nossas ideias sobre as coisas do mundo.

\section{O QUE É UMA CASA?}

Morada, vivenda, habitação, teto, ninho, lugar?

Lugar para morar

\section{Lugar para viver}

Lugar para brincar

Lugar para dançar

Lugar para voar...

\section{Habitar o céu é habitar o grande sonho de voar!!!}

\section{CASATRAMACASATRAMACASATRAMA}
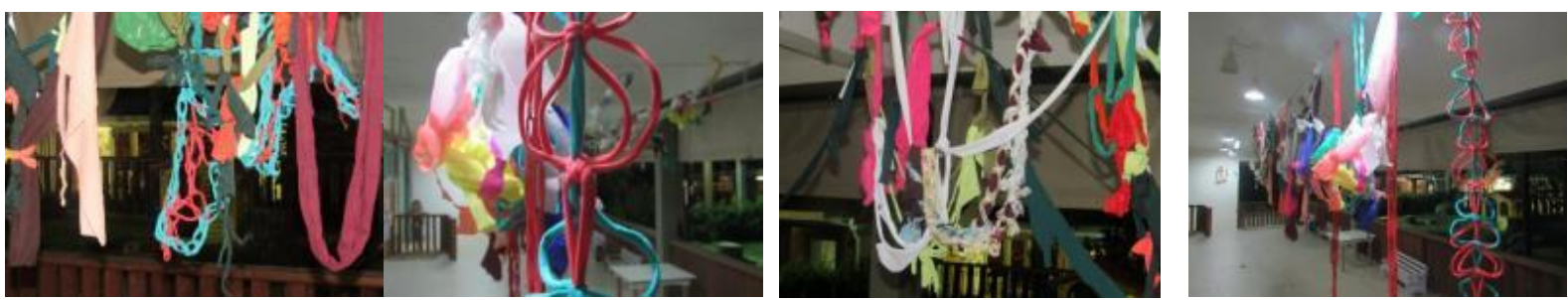

FIG. 4: Tramas para construção de casas. Material elaborado com a participação das crianças e suas famílias. Fotografias. Fonte: Arquivo pessoal da autora. Data: 2017. 


\section{CONSTRUÇÃO DE CASAS/NINHOS}

No início de uma manhã construímos casas/ninhos de diferentes materiais. Tecidos coloridos e enrolados configuraram, no gramado do parque, a ideia de grandes ninhos. Espaços nos quais as crianças puderam se meter, adentrar e se esconder. Uma imagem de abrigo e também de esconderijo.

Para além dos tecidos coloridos e macios, uma grande lona azul compunha o ambiente. A lona com sua consistência mais rígida, possibilitou uma estrutura de ninho mais vertical. Com esta configuração os corpos das crianças foram impelidos a movimentos de oposição, e os jogos de empurrar e derrubar a estrutura foram experimentados com vigor.

Os jogos foram diversos: entrar e sair, esconder-se, ser capturado, escapar, construir e destruir, enrolar-se, deslizaRRRRRRRRRRRRRRRRRRRRRRRRRRRRRR

Para muitas crianças foi o encontro com um espaço acolhedor e confortável. Um lugar/casa onde foi possível brincar de morar/viver.

Um lugar para estar junto com o outro.

\section{CASANINHOCASANINHOCASANINHOCASANINHOCASA}
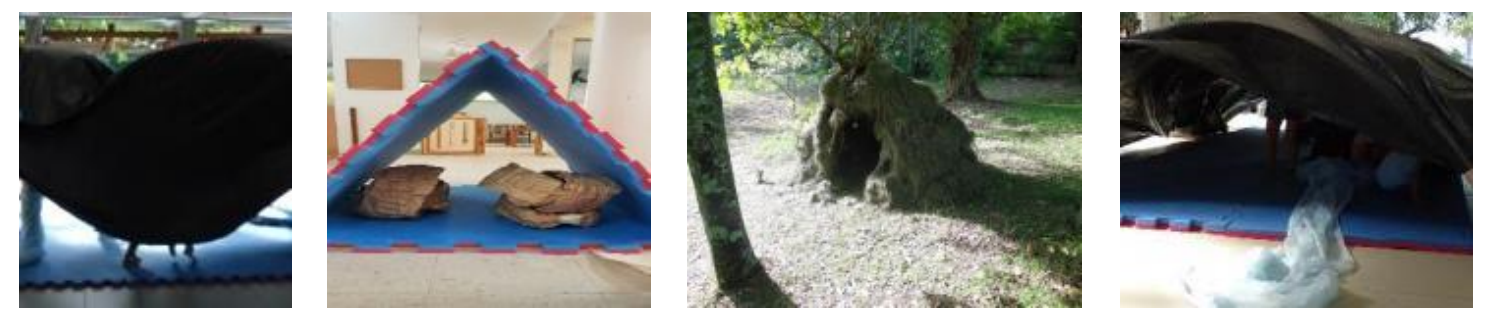

FIG. 5: Construção de casas e ninhos com as crianças. Fotografias.

Fonte: Arquivo pessoal da autora. Data: 2017. 


\section{A PRIMEIRA CASA!}

Depois do momento do lanche, um grupo de crianças foi brincar no parque. Estavam ainda contagiados com as tramas de pássaros que acariciaram a manhã, até então.

No decorrer da brincadeira, conversas sobre casa foram aparecendo... Então, com alguns pedaços de tecidos dependurados no trepa-trepa, uma casa foi, aos poucos, se configurando. Tecidos amarrados no alto do brinquedo caíam até o chão de areia do parque. Assim que a casa ficou pronta, uma família veio para se abrigar. As crianças brincavam enquanto criavam seus próprios enredos.

Desde fora da casa foi possível ouvir de um pássaro:

- Muito obrigado! Vocês cuidaram de mim e agora posso voar...

Logo em seguida, uma criança se aproxima da casa/ninho e diz:

- Hei! eu faço parte desta família.

A criança entra na casa e o que observamos é que ali habita uma família de pássaroscrianças... Ruídos, vozes e sibilos fazem vibrar a pequenina casa de pássaros!!!

- ZiMMMMMMMM; PiU, Piuuuuuuuuuu...

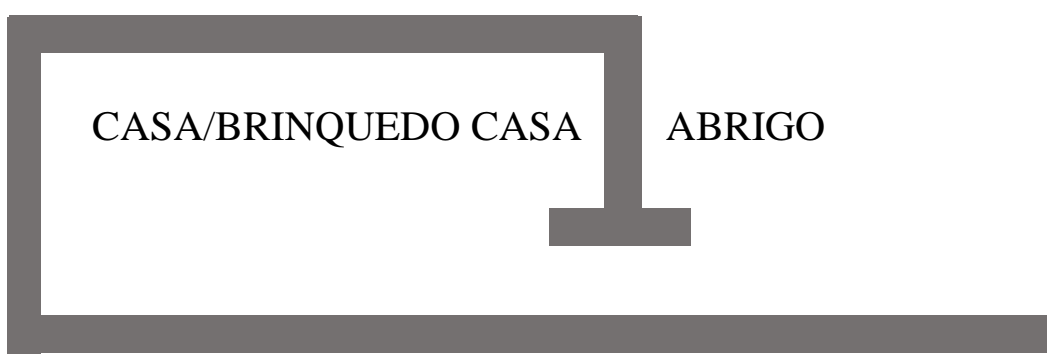

[...] "O ser abrigado sensibiliza os limites de seu abrigo. Vive a casa em sua realidade e em sua virtualidade, através do pensamento e dos sonhos”. (BACHELARD, 1989, p.67) 


\section{TIQUE-TAQUE - TREMOR DAS PEQUENAS COISAS...}
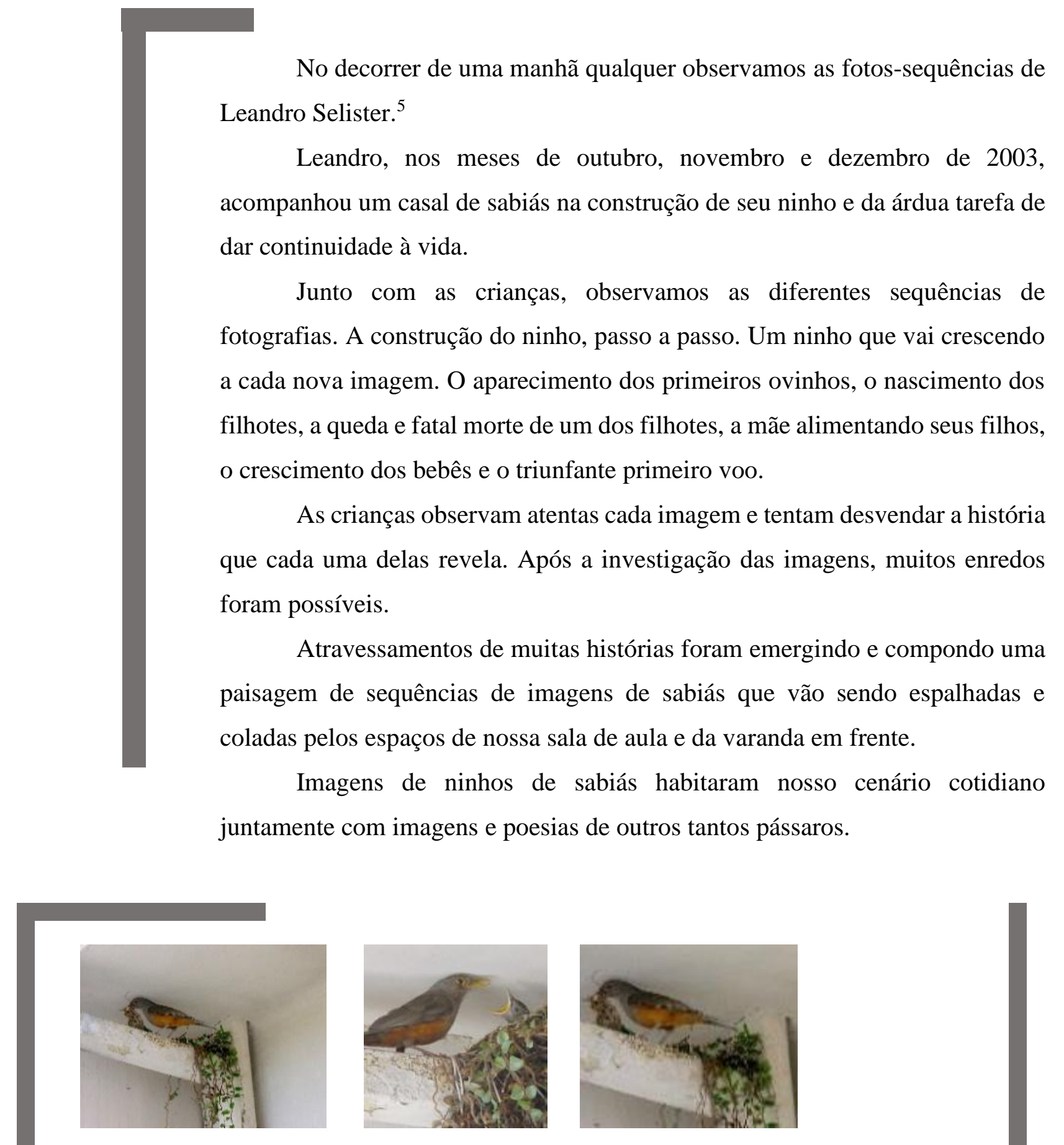

FIG. 6: Casa de sabiá. Fotografias de Leandro Selister.

Fonte:https://www.leandroselister.com.br/blog/portfolio-item/tique-taque-tremor-das-pequenas-coisas/ Acesso em: 19/02/2020

\footnotetext{
${ }^{5}$ Leandro Selister é fotografo, artista plástico. Vive e trabalha em Porto Alegre. Autor do livro, Tique-taque - Tremor das pequenas coisas.
} 


\section{LEANDROSELISTERLEANDROSELISTERLEANDROSELISTERLEANDRO}

Já faz algum tempo que venho trabalhando com registros do cotidiano, de coisas simples e às vezes até banais. Essa atenção voltada ao cotidiano começou em 2003. Eu sempre falo que essa necessidade de captar o tempo, de compreender o tempo através de fotos sequenciais, foi a partir de uma necessidade interna de me entender e de entender também a chegada dos 40 anos, enfim, uma outra etapa na vida. Então, quando completei 38 anos, em 2003, comecei a fotografar tudo o que me possibilitasse entender as transformações, a passagem do tempo. (SELISTER, 2004)
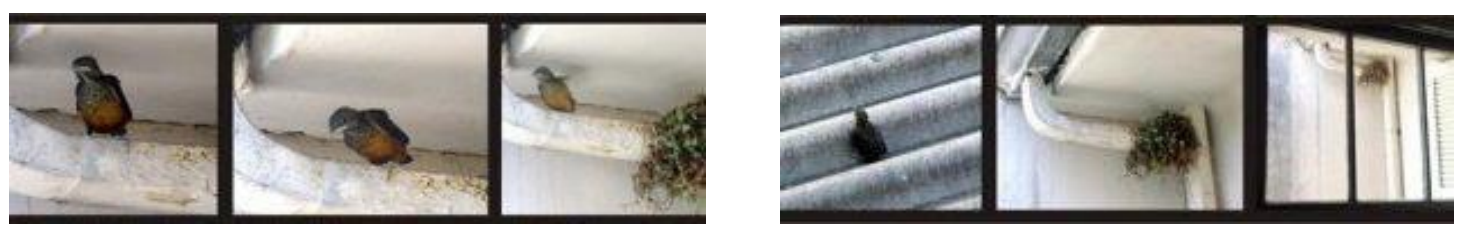

FIG. 7: Casa de sabiá. Fotografias de Leandro Selister.

Fonte:https://www.leandroselister.com.br/blog/portfolio-item/tique-taque-tremor-das-pequenas-coisas/

Acesso em: 19/02/2020

O que está por trás de todas essas imagens que venho realizando há mais de 4 anos, é justamente um olhar mais demorado sobre o mundo, sobre a vida que está acontecendo no nosso quintal, na árvore em frente a nossa casa, na esquina, enfim, coisas que acontecem, coisas belas, e que não temos mais tempo para perceber. (SELISTER, 2004, grifo nosso) 


\section{CASADANÇA}

Das casas-ninhos de pássaros à casa-espetáculo de Deborah Colker. Assistimos numa certa manhã um vídeo: CASA.

Descobrimos que há casas que podem acolher danças, gestos, piruetas e equilíbrios. Que casas são lugares para dançar, cantar, brincar, dormir, comer e...

Segundo Deborah Colker "Construir uma casa é construir espaços. Dançar é ocupar espaços, a arquitetura do movimento".

Deborah Colker sugere que a coreografia do espetáculo CASA, "parte de uma ideia simples, investir nas ações banais para entrar no mundo imaginário e transformá-lo em movimento.” (COLKER, 1999). Seu processo criativo toma o cotidiano como uma importante referência.

A partir do espetáculo, estas também foram questões que nortearam a construção de espaços/casas com as crianças.

Perguntas como o que é uma casa? o que se faz numa casa? como pode ser uma casa? e finalmente, o que pode uma casa? funcionaram como possibilidades de deslocamentos.

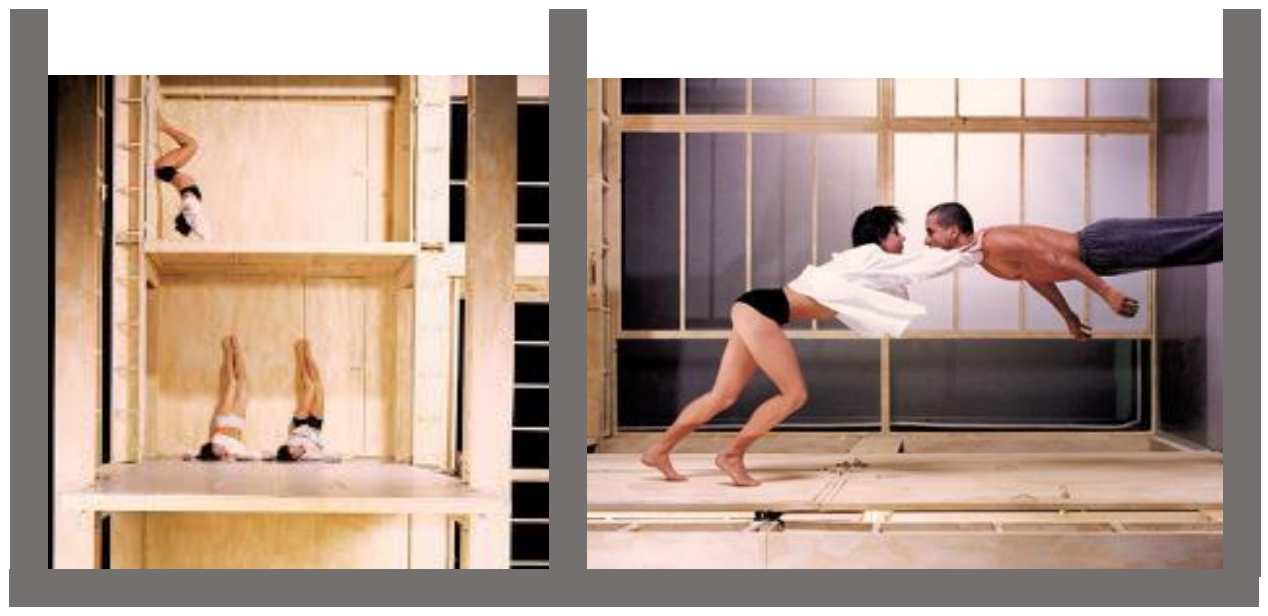

FIG. 8: Espetáculo Casa de Deborah Colker. Fotografias de Flávio Colker.

Fonte: https://www.ciadeborahcolker.com.br/galeria-casa

Acesso em: 19/02/2020

CASADANÇACASADANÇACASADANÇACASADANÇACASADANÇACASADANÇACASADANÇACA 


\section{RESTODECHÃO}

No espaço da Botânica ${ }^{6}$ encontramos um RESTO DE CHÃO e lá arquitetamos uma casa. Sobras de piso quebrado e pequenas muretas foram elementos para nossa construção.

[...] É que crianças, [...] sentem-se irresistivelmente atraídas pelos detritos que se originam da construção, do trabalho no jardim ou na marcenaria, da atividade do alfaiate ou onde quer que seja. Nesses produtos residuais elas conhecem o rosto que o mundo das coisas volta exatamente para elas, e somente para elas. Neles, estão menos empenhadas em reproduzir as obras dos adultos do que estabelecer uma relação nova e incoerente entre estes restos e materiais residuais. Com isso as crianças formam o seu próprio mundo de coisas, um pequeno mundo inserido no grande. (BENJAMIN, 2011, p.57 e 58 , grifo nosso)

Com os restos criamos um ambiente para brincadeiras de INVENTAR de morar.

Mirabolantes jogos de escapar e de prender, e uma casa para nos amparar. Lugar para acolher nossos medos e nos proteger de ameaçadores perigos.

Aos modos do filme DOGVILLE ${ }^{7}$, construímos casas desenhadas no chão!

Concebemos nosso PEQUENO mundo.

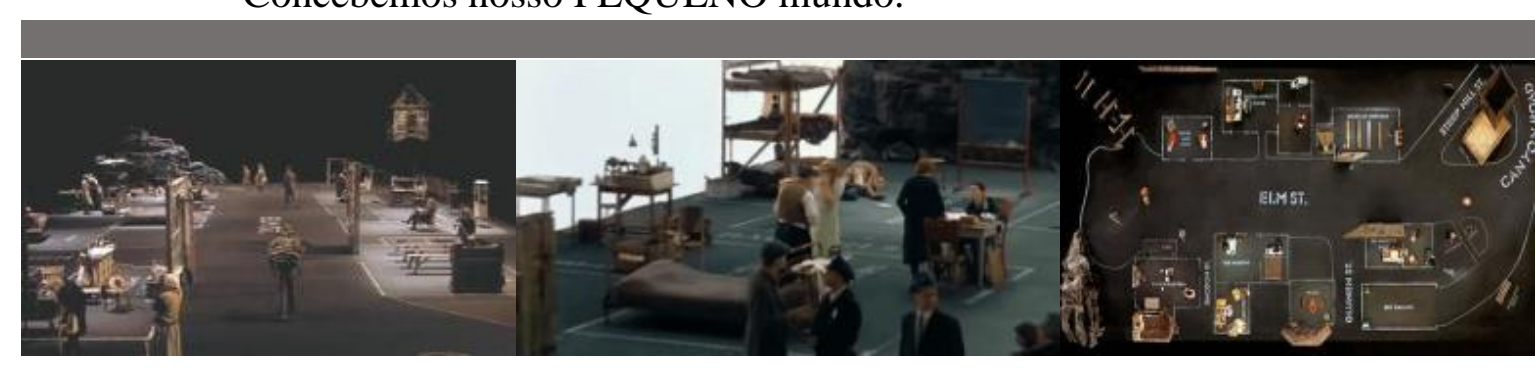

FIG. 9: Imagens do Filme Dogville.

Fonte: https://hombreenlaoscuridad.blogspot.com/2012/06/dogville.html

Acesso em: 19/02/2020

Dogville é um filme que chama nossa atenção pela simplicidade de seus cenários. $\mathrm{O}$ filme foi realizado dentro de um galpão na Suécia, com o mínimo de elementos. Algumas mesas, poucas paredes e apenas demarcações no chão, indicando as casas e outros espaços da cidade. Para o trabalho com as crianças, este cenário inusitado do filme é que nos interessou, na medida em que se aproxima de brincadeiras infantis, nas quais as casas são desenhadas no chão.

\footnotetext{
${ }^{6}$ Botânica: Botânica: Espaço da Universidade Federal de Santa Catarina (UFSC), próximo ao Núcleo de Desenvolvimento Infantil (NDI).

${ }^{7}$ Dogville: Filme lançado em 2003 e dirigido pelo cineasta dinamarquês Lars Von Trier.
} 
Como você é: imagem/mapa para uma pesquisa

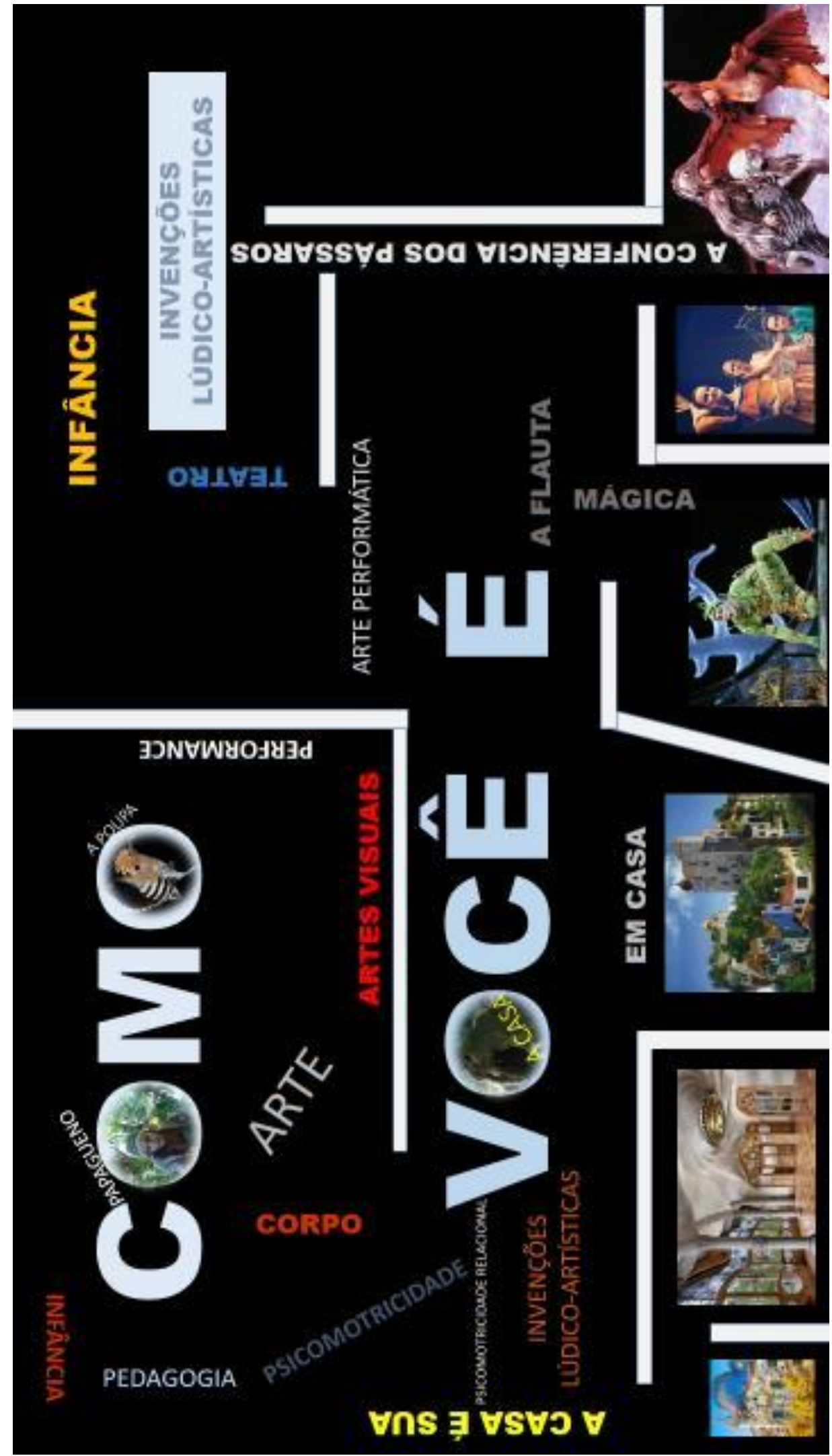

FIG. 10: Mapa/Colagem.

Fonte: Arquivo pessoal da autora. Data: 2019 


\section{Cartografia de um Percurso}

Nos últimos oito anos venho atuando como professora no Núcleo de Desenvolvimento Infantil (NDI), vinculado ao Centro de Ciências da Educação (CED) da Universidade Federal de Santa Catarina (UFSC).

O NDI institui-se como um campo de experimentação pedagógica, da mesma forma que Colégios de Aplicação ligados às Universidades Federais. Funciona como campo de estágio para diferentes licenciaturas da Universidade, assim como também busca implementar o ensino e as alternativas do trabalho pedagógico. Nesse contexto, um conjunto de professoras, do qual faço parte, vem desafiando-se a pensar a docência a partir de outros arranjos. Diferentes organizações de grupos de crianças com variadas faixas etárias e a conciliação de elementos para construção de uma docência compartilhada. A experiência de docência compartilhada acontece com um grupo de professoras que coletivamente planejam, dão cumprimento e avaliam ações educativas com crianças pequenas. Um trabalho polifônico, tramado a muitas mãos e tecido com a sonoridade de muitas vozes.

A partir da experiência corporal trilhada e acumulada em processos de formação embasados pela psicomotricidade ${ }^{8}$, adentrei, em paralelo, o universo artístico. Uma aproximação que se fez como espectadora e também como curiosa, na condição de artista aprendiz.

Chego à arte a partir dos estudos e experiências corporais. Depois de pesquisar sobre o corpo, depois de experienciar meu próprio corpo, percebo que diante das diferentes proposições artísticas ele teima em vibrar descontroladamente. E, não satisfeito na condição de apreciador, arrisca-se como aprendiz em cursos e oficinas de cerâmica, pintura, desenho e colagem.

O conhecimento sobre a arte vem sendo trilhado por meio de leituras, grupos de estudo, grupos de pesquisa, acompanhamento de exposições de artes e de artistas nacionais e internacionais em bienais de arte.

O conhecimento sobre o cenário artístico contemporâneo, minhas experiências como aprendiz de arte e o trabalho de educação desenvolvido com crianças pequenas que frequentam o Núcleo de Desenvolvimento Infantil (NDI/UFSC), têm proporcionado elementos para intervenções lúdico-pedagógicas no âmbito da arte e das expressões corporais. Diferentes

\footnotetext{
${ }^{8} \mathrm{O}$ curso de Mestrado foi em Educação e a área de concentração foi em Prática Psicomotora Aucouturier.
} 
artistas contemporâneos foram abordados como referência, subsidiando as propostas. Determinadas obras funcionaram como disparadores para o incremento do trabalho, alguns artistas eleitos valem-se do corpo e de suas expressões como forma de arte, fator que foi preponderante para a escolha dos mesmos. Um caminho de pensar com os artistas, pensar com suas obras. Um caminho de pensar com a arte.

$\mathrm{Na}$ combinação de elementos advindos da psicomotricidade, da arte performática e outros do cotidiano com as crianças na escola infantil, brotam as Invenções Brincantes/Artísticas.

As Invenções Brincantes-Artísticas tendem a borrar as fronteiras entre professor e alunos; adultos e crianças se misturam num jogo ficcional. Nessas experiências as crianças compartilham com agitações, palavras, alegrias, gestos, silêncios, anseios, danças e gritos. Examinam com cuidado diferentes histórias e reinventam enredos.

A ideia da pesquisa é dar a ver essas proposições. Narrar, esgarçar, tencionar, rever, decompor, analisar, voltar, alterar, INVENTAR. Enfim, um espaço para as invenções.

A escrita acompanha o tom do trabalho construído com as crianças. A composição do texto se dá por imagens, histórias, mapas, cartografias, poemas, músicas, fotografias, cadernos, diários gráficos, caixas/textos.

Em meio ao anuncio de um tema, de um objeto de pesquisa, as nuances de uma história, de um percurso, e das Invenções Brincantes/Artísticas.

Ao modo das crianças pequenas, um olhar para as insignificâncias e atenção para as pequenezas de existências desimportantes.

A construção de uma casa/texto conta a experiência do trabalho sobre casa. Aqui apresento os primeiros movimentos com a casa/texto, ainda a caminhar. 


\section{Esboços para Casa/texto:}

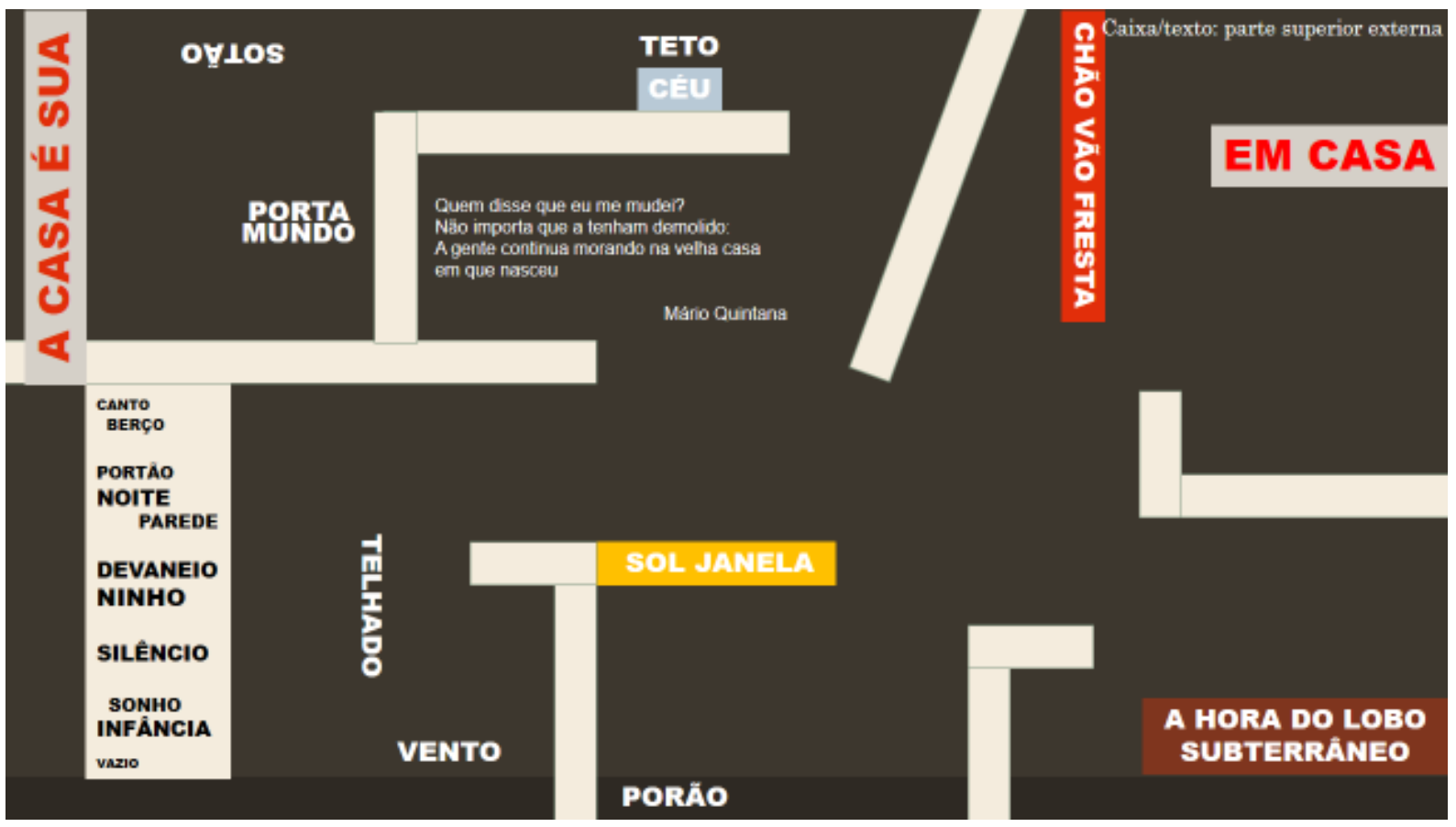

FIG. 11: Projeto para casa/texto. Casa/texto, parte superior externa.

Fonte: Arquivo pessoal da autora. Data: 2019.

\section{Esboços para Casa/texto:}
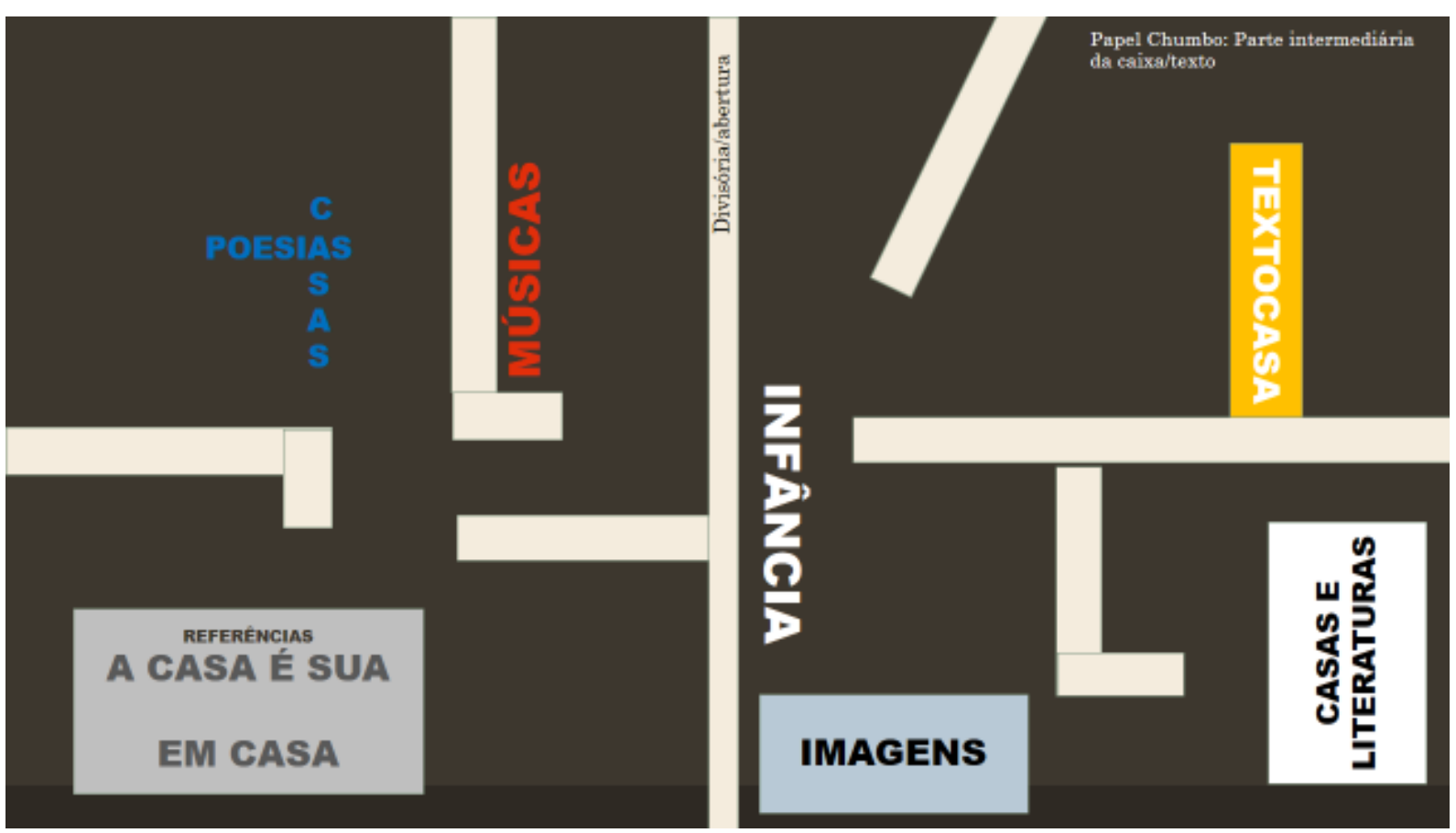

FIG. 12: Projeto para casa/texto. Casa/texto, parte intermediária superior.

Fonte: Arquivo pessoal da autora. Data: 2019. 


\section{Esboços para Casa/texto:}

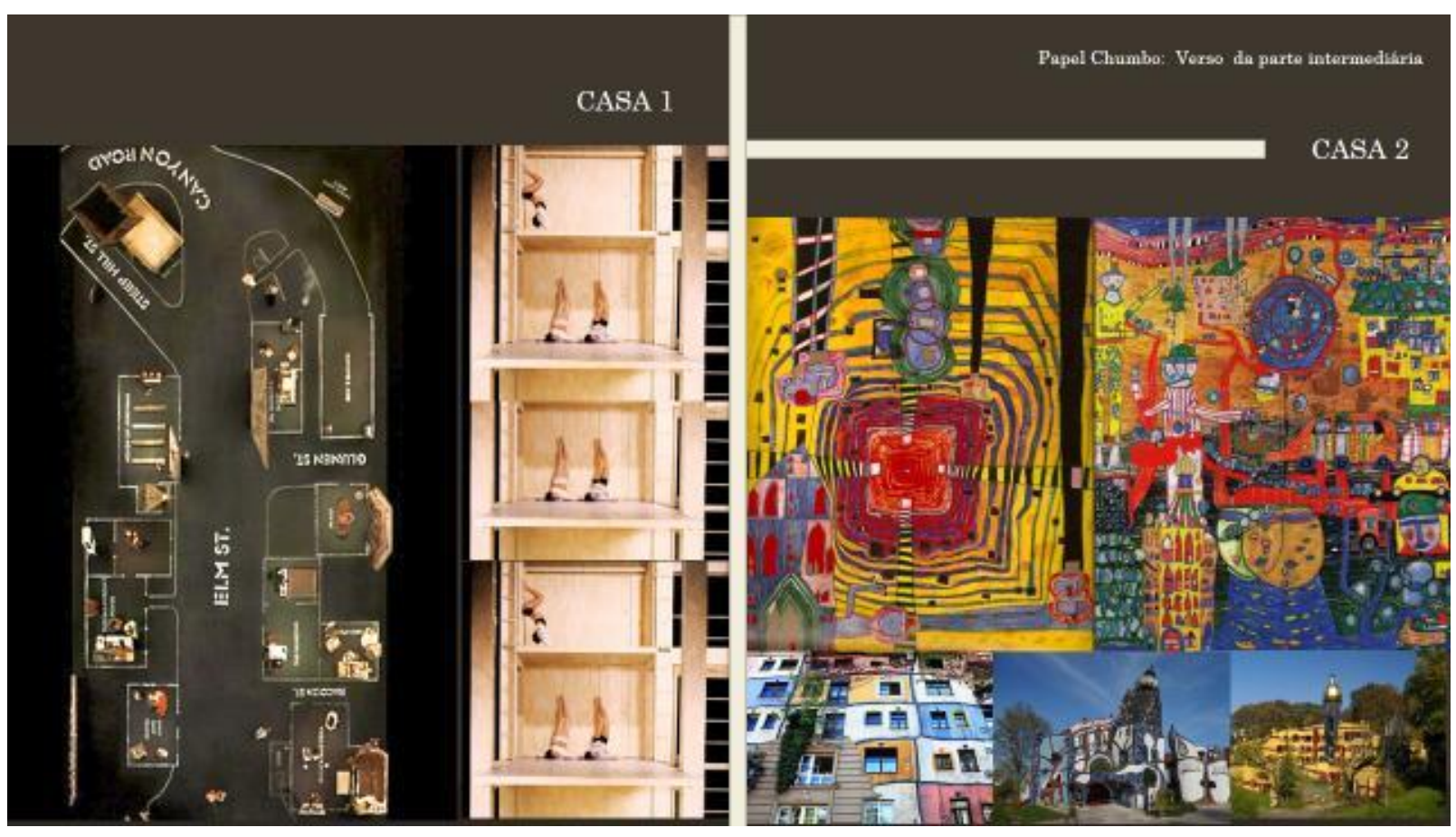

FIG. 13: Projeto para casa/texto. Casa/texto, parte intermediária inferior. Colagem. Fonte: Arquivo pessoal da autora. Data: 2019.

\section{Esboços para Casa/texto:}

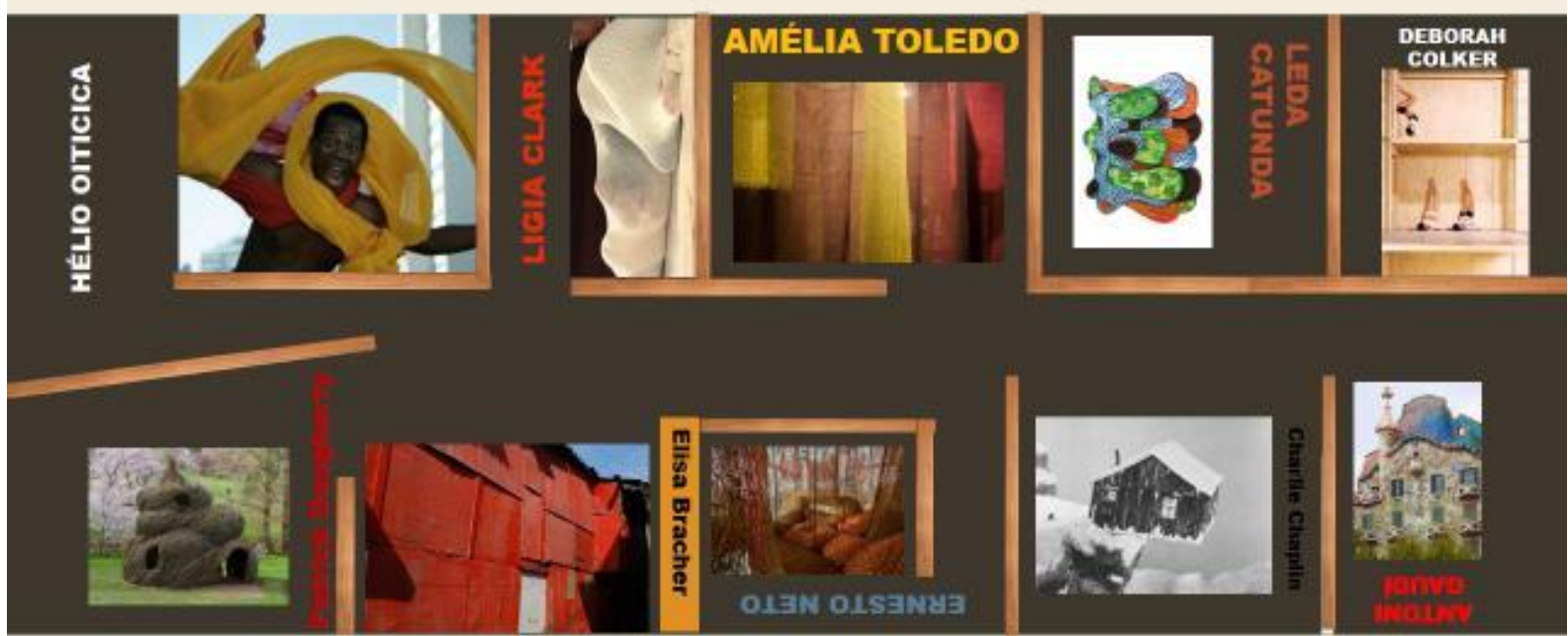

FIG. 14: Projeto para casa/texto. Casa/texto, parte superior interna. Colagem: Os artistas. 


\section{MODOSDECASA}

Existem muitos tipos de casas: ocas, castelos, iglus, sobrados, palafitas, pau a pique. Há também casas de pedra, flutuantes, ou aquelas construídas lá no alto de uma árvore. Ao mesmo tempo em que investigamos e conhecemos diferentes casas, nutrimos nossa imaginação com outras invenções. 1989, p.67)

[...] "todo espaço realmente habitado traz a essência da noção de casa". (BACHELARD,

CASASDEROGERMELLO

\section{PALAFITAPALAFITAMANGUEPALAFITACASADOVIZINHOVIZINHA}

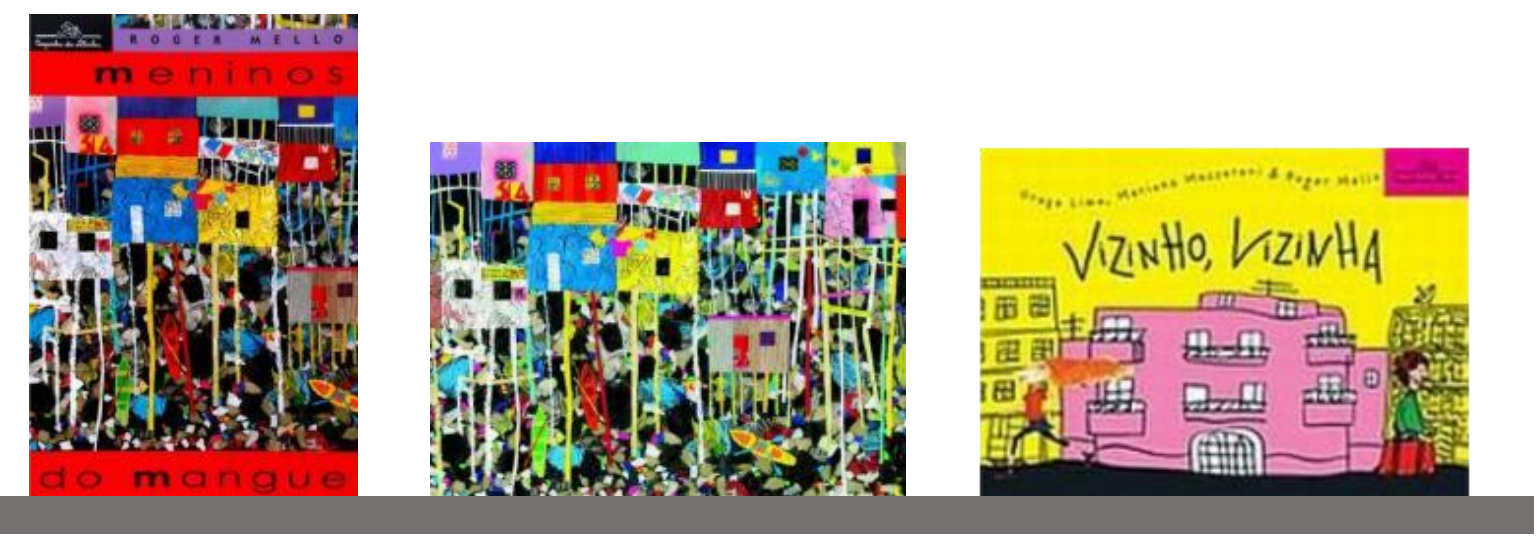

FIG. 15: Ilustrações de Roger Mello, Graça Lima e Mariana Massarani.

Fonte:http://www.universohq.com/noticias/brasileiro-roger-mello-ganha-o-premio-hans-christian-andersen/ Acesso em: 19/02/2020

\section{CASASVOLPICASASVOLPICASASVOLPICASASVOLPICASASVOLPI}

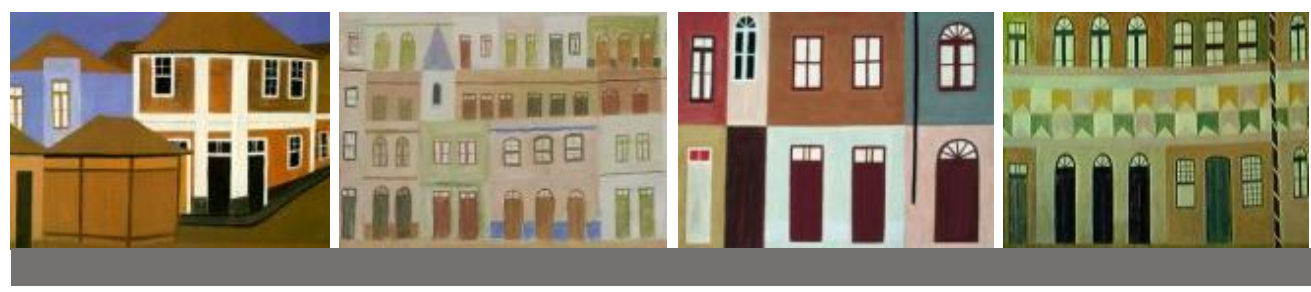

FIG. 16: Casas de Alfredo Volpi.

Fonte: https://www.wikiart.org/en/alfredo-volpi - Acesso em: 19/02/2020 


\section{CASATECIDO}

Movidos pelos tecidos moles de Leda Catunda, pelo túnel envoltório de Lygia Clark e pelas casas/labirintos de Amélia Toledo, BRINCAMOS.

O tecido que prende, que laça e enlaça,

O tecido que aquece, acolhe e abriga,

O tecido que voa brincante no ar!

O tecido que enrola, circula e protege feito casa.

De cor em cor, de textura em textura, de nó em nó...

Tecidos como casas!

ENVOLTÓRIOLYGIACLARK

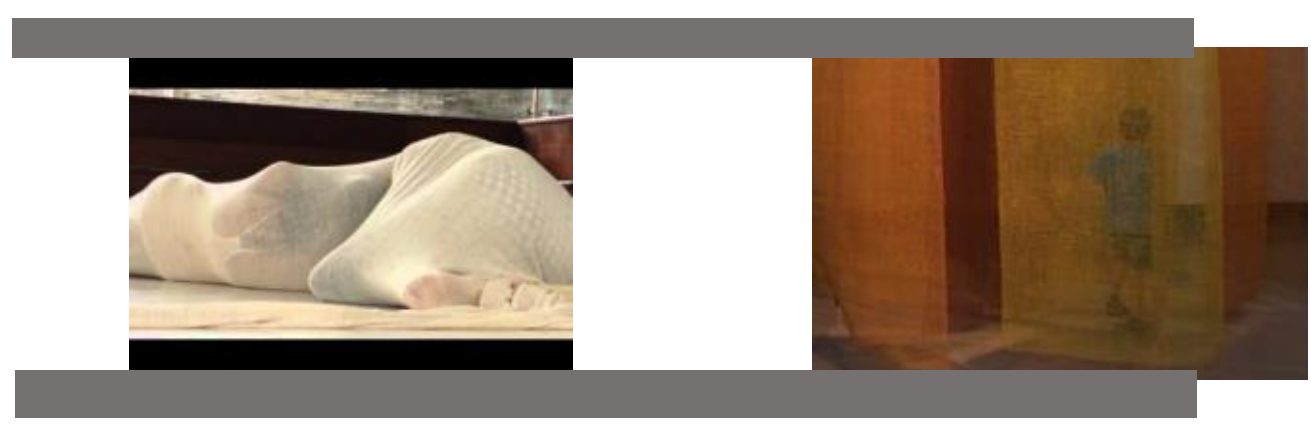

FIG. 17: Imagens de obras de Lygia Clark e Amélia Toledo.

Fonte: https://www.youtube.com/watch?v=nsmk5L_OkCI

https://ameliatoledo.com/obra/obras-publicas-e-instalacoes/

Acesso em: 19/02/2020

[...] "uma casa, uma membrana entre o corpo e a noite" (MARQUES, 2017, p.11) 


\section{NINHOCASA}

O que era casa virou ninho, o que era ninho transmutou-se em casa. Erguemos um grande ninho no espaço do Bosque.

Em bando, adentramos o bosque para juntos realizarmos a construção de um grande ninho/casa. Próximo ao tronco de uma árvore, juntamos galhos, gravetos e palha...

O ninho/casa foi reduto de nossas andanças, brincadeiras e fantasias.

Como é bom sonhar/brincar no aconchego de nosso bando. Como é bom sonhar no segredo de nossa casa.

[...] "a casa abriga o devaneio, a casa protege o sonhador, a casa permite sonhar em paz".

(BACHELARD, 1989, p. 68)
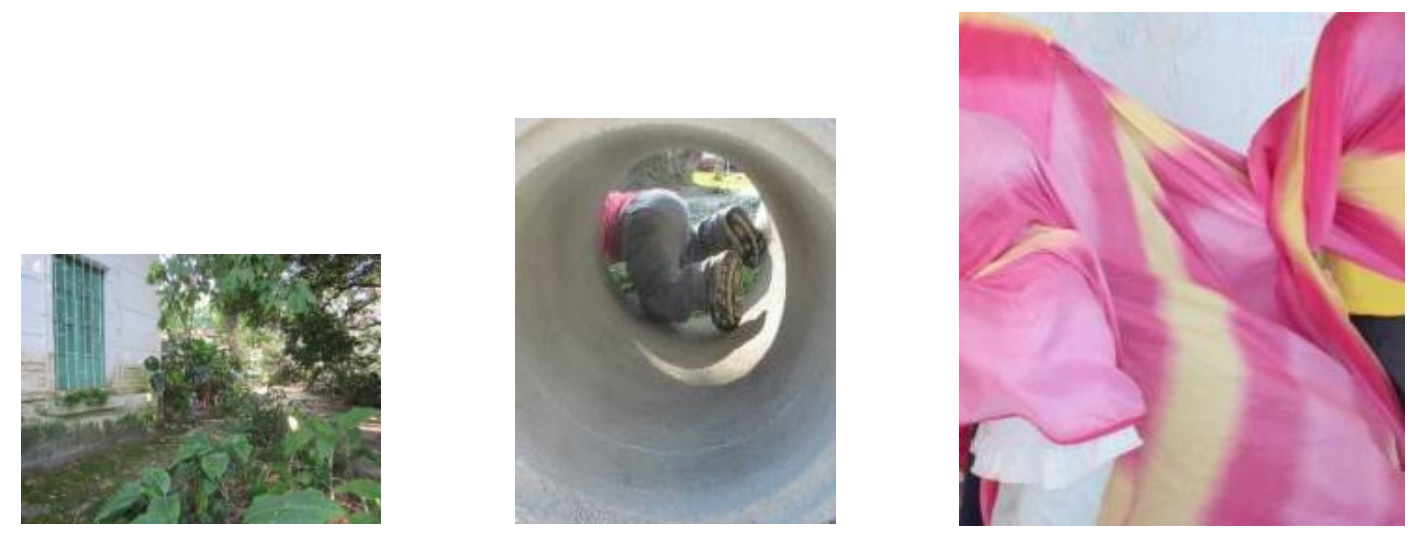

NINHOCASANINHOCASANINHOCASANINHOCASANINHOCASA

FIG. 18: Imagens de casas inventadas e exploradas com as crianças. Fotografias.

Fonte: Arquivo pessoal da autora. Data: 2017 


\section{CASACAIXA CASAMALA CASAVIAGEM CASAVOO}

De uma caixa de papelão chega-se a uma mala, a caixa como mala.

O que é uma mala?

Uma mala é um objeto carregador de coisas, objeto que carrega outros objetos.

O que é uma mala?

A mala é um objeto de viagem. É uma mala/viagem.

Eis as viagens da mala:

A casa como caixa,

A caixa como mala,

A mala como viagem!

Uma mala convida para uma viagem. A viagem é um convite para o voo. $\mathrm{O}$ voo impele a sair do chão, desprender os pés e voar...

Durante o voo a mala traz uma revelação! A mala guarda dentro de si uma roupa de pássaro. O pássaro é a Poupa, a Poupa era um poeta e agora é um pássaro.

A Poupa conta uma história, a história é uma viagem, a viagem é uma busca.

Os caminhos? Os trajetos?

Insólitos, incomuns, excêntricos, inesperados!!! 


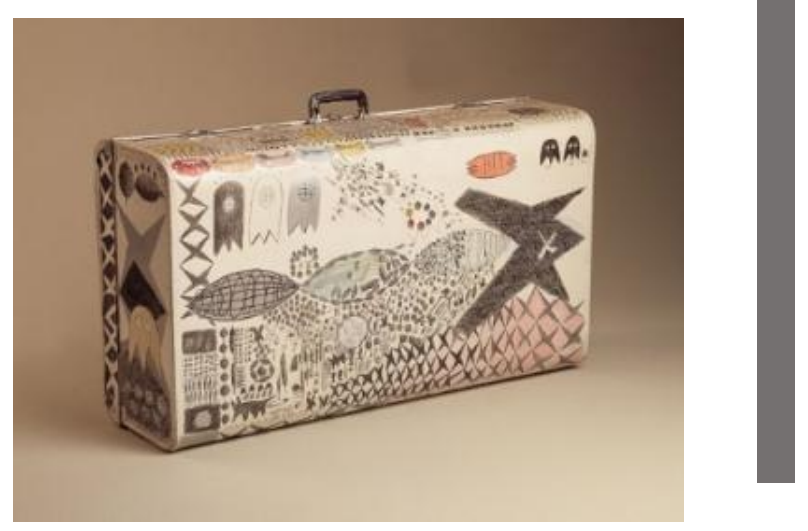

FIG. 19: A Mala, 1986/87. Obra de José Carratu.

Fonte: http://www.mac.usp.br/mac/expos/2015/casa/galeria.htm - Acesso em: 20/02/2020.

As casas abandonam a si mesmas

fogem de si mesmas

um dia você retorna

e a casa não está lá

está apenas seu molde

casca ou carcaça

sai então à caça

da casa

\section{EM VIAGEM}

ou fica lá

onde já não está

(MARQUES, 2017, p.45, grifo nosso) 


\section{A CONFERÊNCIA DOS PÁSSAROS!}
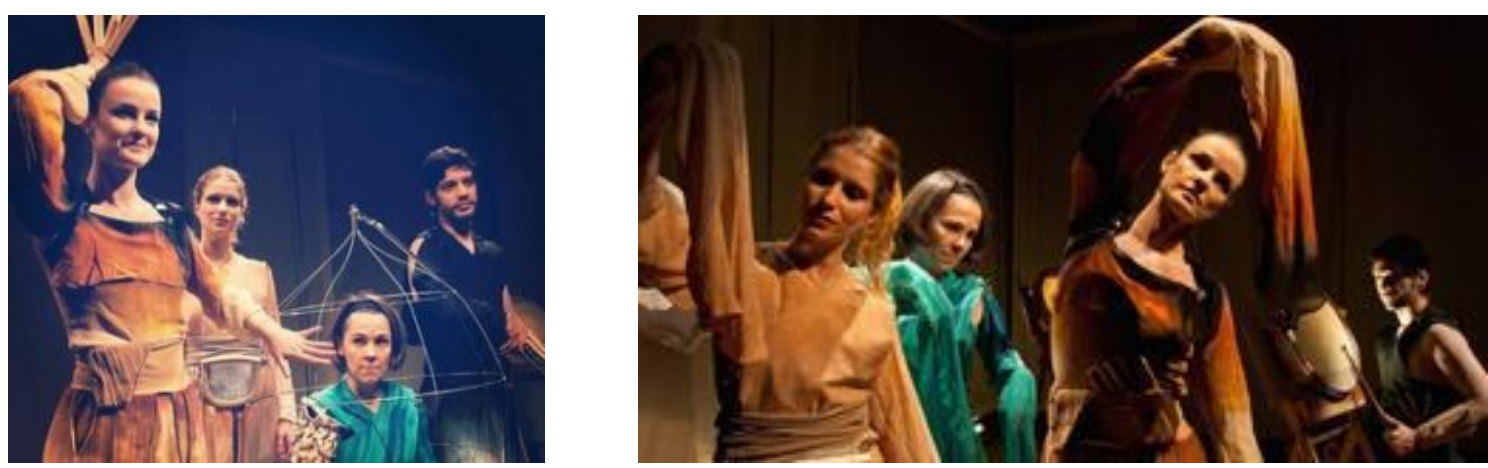

FIG 20: Espetáculo: A Conferência dos Pássaros. Direção de Mauricio Grecco. Fotografia: Nana Moraes

Fonte: https://cbtij.org.br/conferencia-dos-passaros-direcao-mauricio-grecco/ - Acesso em: 20/02/2020

O rei dos pássaros, Simorg, deixa cair no meio da noite, no chão da China, uma de suas penas...

O poeta Attar acorda numa certa manhã e depara-se com um inquietante acontecimento: havia se tornado um pássaro, uma Poupa.

A Poupa organiza uma grande reunião com todos os pássaros do mundo. O apelo é a busca pelo Rei Simorg, aquele que saberá a resposta para tantos desalentos, num mundo repleto de revoltas e disputas.

Os pássaros, conduzidos pela Poupa, empreendem uma viagem cheia de aventuras e desafios, superam os sete vales na procura da montanha de Kaf, onde vive o Rei Simorg.

Durante o percurso, muitos viajantes se perdem, desistem, perecem. Mas, ao final, no encontro com o Grande Rei, descobrem que sempre estiveram muito próximos do que buscavam.

Governados pela narrativa da Conferência dos Pássaros realizamos um sem fim de experiências.

[...] "Viajar então era isso? Ver sua casa pelo lado de fora?" (MELLO, 2018, p.49, grifo nosso) 


\section{PASSO A PASSO...}

vamos chegando ao final desta história, e aqui ela provisoriamente termina para depois abrigar outras,

noutros tempos, lugares e começos.
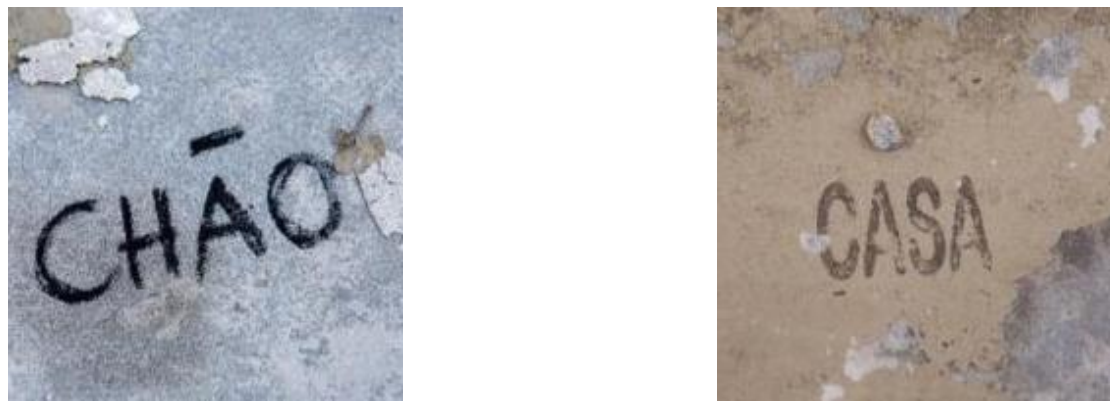

FIG. 21: Uma casa desenhada no chão. Casa/palavra. Fotoperformance. Fotografias de Soninha Vill.

Fonte: Arquivo pessoal da autora. Data: 2019.

[...] "A casa é nosso canto no mundo". (BACHELARD, 1989, p. 67)

No movimento de encadear ideias, objetos, pensamentos, arte, brincadeira, escola, imagens, cinema, poesia, dança, música, palavras e tantos outros elementos que sejam possíveis, acontecem outras conformações, sempre renováveis, a depender das contribuições.

Cria-se um entrelugar para a escola, para a arte, para a infância, para a vida.

Fazem-se brotar Invenções Brincantes-Artísticas.

Um cenário de INVENÇÕES deflagra performatividades. Numa contextura performativa toda a escola infantil performa, o currículo, os métodos de ensino, as proposições pedagógicas, os espaços, os materiais, os tempos escolares, as crianças, as professoras. 
as crianças não se cansam esgotam suas energias, caem dentro do sono mas não se cansam o cansaço é o fim da infância pode ser que seja assim que só para elas exista CASA absolutamente

(MARQUES, 2017, p.20)

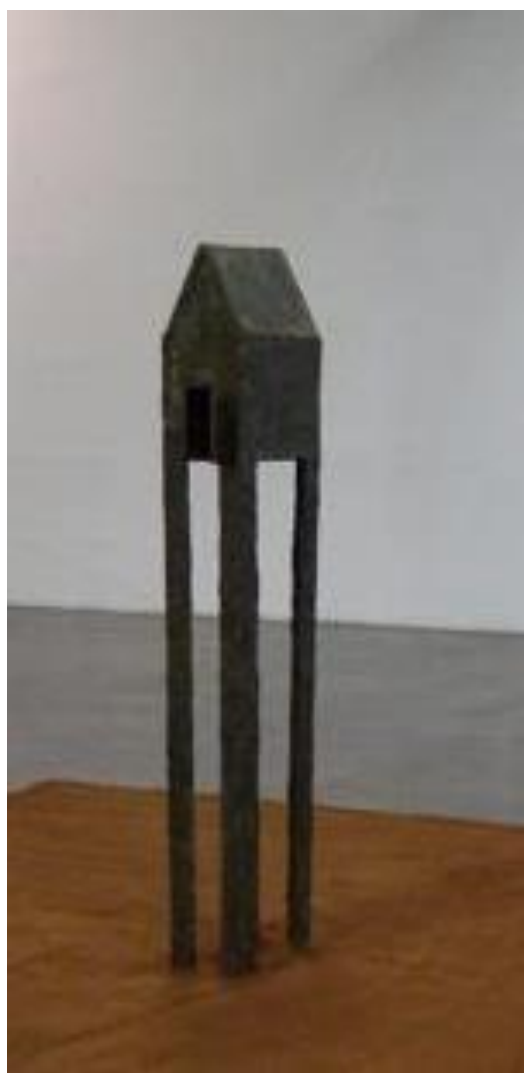

FIG 22: Casa, 1995. Obra de Maria Tomazelli.

Fonte: http://www.mac.usp.br/mac/expos/2015/casa/galeria.html

Acesso em: 20/02/2020.

PARA POESIA E PENSAMENTO SOBRE AS COISAS DO MUNDO, A CASA 
PARA POESIA E PENSAMENTO SOBRE AS COISAS DO MUNDO, A CASA

Com InveNções de: 


\section{REFERÊNCIAS}

ATTAR, Farid al-Din. A linguagem dos pássaros. São Paulo: Attar Editorial, 2011.

BACHELARD, G. A Poética do Espaço. São Paulo: Martins Fontes, 1989.

BENJAMIN, W. Reflexões sobre a criança, o brinquedo e a educação. São Paulo: Editora 34, 2009.

BRACHER, E.; VALENTIM, F.; NAVES, R. A cidade e suas margens. São Paulo: Editora 34, 2008.

CASA. Criação, Direção e Coreografia: Deborah Colker. Rio de Janeiro: Dan Hassan, 1999. 1 DVD (60 min.), son., color.

A CASA. Intérprete: Boca Livre. In: A Arca de Noé, [S. I..]: Gravadora Ariola , 1980. 1 disco sonoro, faixa 2, lado 2 (2 min., 13 sec.). Disponível em:

http://www.toquinho.com.br/album/lp-a-arca-de-noe-1-polygram-1980/. Acesso em: 3 mar. 2020

A CASA é sua. Intérpretes: Arnaldo Antunes/Ortinho. In: Ao vivo lá em casa. Intérprete: Arnaldo Antunes. [S. I.] : Gravadora Rosa Celeste, 2010. 1 CD, faixa 1 ( 4 min., $41 \mathrm{sec}$.) Disponível em:

https://open.spotify.com/track/0QjxHLuEJHmAFDyMkEDf7z. Acesso em: 08 mar. 2020.

CASA é Sua - Arnaldo Antunes: videoclipe oficial (Projeto 3 Clipes - 1 Curta) . Publicado on-line pelo canal Três Clipes. Disponível em:

https://www.youtube.com/watch?v=Y-xVpQ1KRWw. Acesso em: 20 fev. de 2020.

CHIARELLI, T. Leda Catunda. São Paulo: Cosac \& Naify Edições, 1998.

COLKER, D.; BOSCO, F.; ELIAS, J. Companhia de dança Deborah Colker. Rio de Janeiro: Réptil, 2013.

DOGVILLE. Direção: Lars Von Trier. Dinamarca: California Filmes, 2003. 1 DVD (171 min.), son., color. Legendado.

EM BUSCA do ouro. Direção : Charles Spencer Chaplin. Produção de United Artists. Estados Unidos: Charlie Chaplin Film Corporation, 1925. 1 DVD (96 min.) P\&B.

ERNESTO NETO. São Paulo: Itaú Cultural, 2020. Website: Enciclopédia Itaú Cultural de Arte e Cultura Brasileiras. Disponível em:

https://enciclopedia.itaucultural.org.br/pessoa11848/ernesto-neto. Acesso em: 19 abr. 2020.

LALAU; LAURABEATRIZ. Passarinhos do Brasil: poemas que voam. São Paulo: Peirópolis, 2013. 
LALAU; LAURABEATRIZ. Sobre Voos: o que as aves brasileiras veem lá de cima. São Paulo: Editora Manole, 2008.

LOVE Casa Batlló. Barcelona: Vimeo, 2013. 1 vídeo (2 min., 34 sec.) son. color. Disponível em: https://vimeo.com/81086090. Acesso em: 3 mar. 2020.

MARQUES, A. M.; JORGE, E. Como se fosse a casa: (uma correspondência). Belo Horizonte: Relicário Edições, 2017.

MELLO, R. Meninos do Mangue. São Paulo: Companhia das Letrinhas, 2001.

MELLO, R. Clarice. São Paulo: Global, 2018.

MELLO, R. Vizinho, Vizinha. São Paulo: Companhia das Letrinhas, 2002.

PÁEZ VILARÓ, C. Museo-Taller de Casapueblo (Uruguai). Uruguai : Casapueblo, 2015. Facebook: @museotallerdecasapueblo. Disponível em:

https://www.facebook.com/museotallerdecasapueblo/. Acesso em: 03 mar. 2020.

PATRICK Dougherty. Publicado on-line pelo site Patrick Doucherty, News, Carolina do Norte : [s . n.], 2015. Disponível em: http://www.stickwork.net/news. Acesso em: 03 mar. 2020.

PINACOTECA DO ESTADO DE SÃO PAULO. Lygia Clark da obra ao acontecimento: somos o molde : a você cabe o sopro. [Catálogo]. Curadoria: Suely Rolnik; Corinne Diserens. São Paulo: Pinacoteca do Estado de São Paulo, Organização Social de Cultura, 2005.

QUINTANA, M. Preparativos de Viagem. Rio de Janeiro: Alfaguara, 2013.

RESTANY, P. Hundertwasser: o pintor das cinco peles. Lisboa: Taschen, 2003.

SELISTER, L. Leandro Selister: paixão por capturar imagens que marquem a passagem do tempo. [S. I] : Dana. Website: Dana, entrevistas. Disponível em: https://dana.com.br/social/entrevistas/leandro-selister/. Acesso em: 03 mar. 2020.

SELISTER, L. Tique-taque tremor das pequenas coisas. Porto Alegre: Escritos, 2014.

SELISTER, L. Tique-Taque, tremor das pequenas coisas. [S. I. : s. n.], 2004. Blog: Leandro Selister, projetos. Disponível em:

https://www.leandroselister.com.br/blog/portfolio-item/tique-taque-tremor-daspequenas-coisas/. Acesso em: 03 mar. 2020.

SíS, P. A Conferência dos Pássaros. São Paulo: Companhia das Letrinhas, 2013.

TOLEDO, A. Amélia Toledo: arte, liberdade, aventura. [S. I. : s. n.], 2017. Website: Amélia Toledo Disponível em: https://ameliatoledo.com/artista/. Acesso em: 3 mar. 2020. 